\title{
An Ecosocial Reading of Slow Violence in Latife Tekin's Manves City
}

\author{
Öğr. Gör. Dr. Özlem Akyol \\ Pamukkale Üniversitesi, Yabancı Diller Yüksekokulu \\ ozlemakyol12@gmail.com
}

\begin{abstract}
Ecocriticism is an increasingly heterogeneous movement under which a variety of approaches fall. One of these approaches is Ecosocialism which expands the critical scope towards environmentally serious social issues within cities. The theory combines revolutionary and green perspectives to promote equality and living in harmony with nature in a classless society. At this point, Rob Nixon's innovative concept 'slow violence' of which effects are not immediate but dispersed time and space has been frequently associated with Ecosocialism. Through ecosocial lenses, slow violence can be considered as a common threat for environment and society since the theory perceives both as cheap resources gradually exploited for profit. The environmental and social effects of such violence strikingly appear in Latife Tekin's Manves City ${ }^{1}$ (2018) in which a post-industrial small town and its inhabitants' tragic lives are portrayed. Based on Tekin's socialist and green perspectives which are frequently adopted in her literary works, Manves City, in which exploitative attitude of employers towards nature and workers and the gradual extinction of nature in parallel with the degradation in domestic life of local people are discussed as essential themes, lends itself Ecosocial criticism. In analyzing the novel through ecosocial lenses, the paper also aims to reveal the interacting relation between environmental and social degradation through Tekin's depiction of slow violence.
\end{abstract}

Keywords: Ecosocialism, slow violence, Rob Nixon, Latife Tekin, Manves City.

\section{Latife Tekin'in Manves City Adlı Romanında Yavaş Şiddet Kavramının Ekososyal Bir Okuması}

\section{Öz}

Ekoeleştiri altında birçok farklı yaklaşımın toplandığı gittikçe çok unsurlu hale gelen bir akımdır. Bu yaklaşımlardan bir tanesi de eleştirel boyutunu şehirlerdeki çevresel bakımdan kritik konulara kadar genişleten Ekososyalism teorisidir. Teori, sınıfsız bir toplumda doğa ile uyum içinde yaşamayı ve eşitliği ön plana çıkarmak adına devrimsel ve çevreci bakış açısını ortak bir noktada birleştirir. Bu anlamda, Rob Nixon'un ürettiği o anda etkisi hissedilmeyen ancak zaman ve mekâna yayılan "yavaş şiddet" kavramı sıklıkla ekososyalism ile ilişkilendirilir. Ekososyalist bakış açısından bakıldığında yavaş şiddet toplum ve çevre için ortak bir tehdit olarak düşünülebilir çünkü bu bakış açısı hem toplumu hem de çevreyi kar elde etmek için giderek daha fazla sömürülen ucuz kaynak olarak görür.

${ }^{1}$ It is not possible to find the English translated versions of Manves City. Therefore, the right of the translation of the Turkish extracts into English is reserved for me. 
Bu tür bir şiddetin sosyal ve çevresel etkileri endüstri devrimi sonrası küçük bir kasabayı ve orda yaşayan insanların trajik hayatlarını resmeden Latife Tekin'in Manves City (2018) adlı romanında çarpıcı bir şekilde ortaya koyulur. Tekin sosyalist ve çevreci düşüncelerini edebi eserlerinde sıklıkla yansıtır. Bu anlamda işverenlerin işçilere ve doğaya karşı olan sömürgeci tutumunun ve yerel insanların özel hayatlarındaki çöküşe paralel olarak gittikçe yok olan doğanın ana tema olarak işlendiği Manves City romanı ekososyal eleştiriye açıktır. Bu çalışma romanı Tekin'in "yavaş şiddet" tasviri üzerinden ekososyal bakış açısından okuyarak sosyal ve çevresel çöküşün karşılıklı ilişkisini ortaya çıkarmayı amaçlar.

Anahtar Kelimeler: Ecososyalizm, yavaş şiddet, Rob Nixon, Latife Tekin, Manves City. 


\section{INTRODUCTION}

Ecosocialism has been an issue addressed by an increasing number of literary studies in recent years. It is an approach which combines the ideas of ecology and socialism. Ecosocialists assume that people in the modern world cannot make decisions favoring nature without considering profit calculations. In this sense, capitalism which aims to expand profit without considering social and ecological consequences and propagates the infinite and expansive pattern of production and consumption, is at the critical target of Ecosocialism. Capitalism is triggered by the Industrial Revolution which is one of the vital factors behind globalization process. While globalization's driving force is the capitalist world economy, its implications have been recently felt in many different fields such as politics, environment, lifestyles and society. The process which is seen as a new phase in modernity development (Giddens, 1990) gradually causes fragmentation in culture, identity and locality though many believe in its homogenizing impact. Kovel and Lövy both known as founders of the theory define globalization as "the form of imperialism [...] with its disintegrative effects on societies" (2001, p. 1). Yet, it has developed inadequate critical attitude toward the destructive relationship of industrial civilization with nature. Moreover, the theory promoted the idea of human's absolute mastery over nature. Such perspectives contradict any severe theoretical and practical consideration of environmental issues such as overuse of natural resources or inadequate attention to nonhumans' intrinsic values.

However, at the threshold of the 21st century, as the threats about the planet resulting from the current production pattern and consumption grew, it required that Marxist theory break radically with technical and financial paradigm of industrial civilization which disregards the preservation of environment. The growing threats for ecological balance have led to emergence of catastrophic scenarios on the human species' survival. At this point, ecologists would be wrong if they imagined they could handle the ecological issues without Marxist criticism of capitalism since "An ecology that does not recognize the relation between 'productivism' and the logic of profit is destined to fail or, worse, to become absorbed by the system" (Löwy, 2005, p. 17). Also, as consumerism is a significant threat to environmental preservation, Marxism favoring use-value could be placed in ecological paradigm. Therefore, a productive space has been created by ecosocialists who are aware that workers and their associations cannot be separated from any radical change on behalf of ecological thought and are an integral part for the formation of a new socialist and environmental society.

For the last 40 years, Ecosocialism has developed thanks to the works of critical theorists and authors like Raymond Williams, Rudolf Bahro, Andre Gorz as well as other prominent figures such as James O'Connor, Barry Commoner, Ian Angus, John Bellamy Foster, Joel Kovel, Jorge Riechman, Jean-Marie Harribey, Michael Löwy, Frieder Otto Wolf, and many others. They publish mostly in the journals named Capitalism Nature Socialism and Ecologia Politica. Their common aim is to indicate that Ecosocialism leads to the emergence of ecologically rational and democratically controlled society in which the use-value of any product is favored. In parallel to all these ecosocial premises, there is another concept called "slow violence," a global phenomenon which is rooted in the colonizing period and affects societies and their environments. Since the literary scholar Rob Nixon published the book Slow Violence and the Environmentalism of the Poor in 2011, the phenomenon has become one of the most frequently applied and cited concepts in the ecocritical studies. He describes the

SEFAD, 2021; (46): 139-152 
idea as "calamities that are slow and long lasting, calamities that patiently dispense their devastation while remaining outside our flickering attention spans and outside the purview of a spectacle-driven media" (Nixon, 2011, p. 6). This large-scale, structural and extensive form of violence, which is elaborated in Nixon's book, is complicated to grasp instantly for the human mind. Therefore, he argues that "to engage slow violence is to confront layered predicaments of apprehension, to apprehend-to arrest, or at least mitigate-often imperceptible threats require rendering them apprehensible to the senses through the works of scientific and imaginative testimony" (Nixon, p. 14). In this sense, literary studies render the unnoticed threats visible within this paradigm. In reality, the violence that Nixon speaks of mostly goes unnoticed in many parts of the world since it usually affects the countries located in global South which is an emerging term referring to the politically or culturally marginalized regions mostly with low income. This is the intersection where the concept of slow violence and the theories of Ecosocialism meet. In the literary narratives, including the experiences of people from global South, temporally and spatially extensive effects of slow violence could become apprehensible through the lenses of Ecosocialism.

Starting from this point of view, in Manves City, Latife Tekin focuses on a countryside community that has recently evolved into a labor society due to newly built factories in the region. This transformation induces great traumatic changes in communal and individual basis and irreparable damage to the environment of "Erice," which renders the town into a sacrifice zone. This zone is called with the eponymous word Manves City which is also defined as apos-industrial town. The first sign of capitalism is giving this local place in Turkey an English name, which signifies the global power of the system. The novel basically revolves around the story of Ersel, who is an ex-factory worker and just released from the prison. He has difficulties in adapting to the new version of Erice after many years spent in the prison. Although it is a real challenge to find a job for him, he starts working in a farm as a milker with the help of the man he has met in the prison. Simultaneously, he starts searching for his step-daughter Eda, who has been missing for a long time. Eda has never physically appeared in the narrative but has been depicted through memoirs of other characters. After being lost, she has been exposed to sexual harassments many times until her dead body is found in the wilderness. Ersel's quest for Eda and his own identity is accompanied with Nergis's nostalgic memoirs related through her writings in a local newspaper. Therefore, by means of various perspectives, Tekin tries to depict the changing panorama of the town which is in the middle of industrialization process. She puts extra emphasis on the gradually devalued environment and the locals' lives disturbed by global capitalism and exploitation. The twofold damage as a result of this devaluation manifests the effects of slow violence. In Manves City, the violence is, as Nixon puts, depicted as "accretive and attritional" in such a way that Manves holding, which is portrayed as a repercussion of mechanization process and capitalism, not only corrupts sequential structure of nature but also domestic and social values in Erice. Accordingly, Tekin narrates the people who have to bear witness to the morally and ecologically corrupted town and their miserable lives smashed under the wheels of capitalism. The intermingling relation of social and ecological corruption will be apparent when Ecosocial critical theories are adopted to the novel.

\section{Environmental Degradation in Erice}

For the last two decades, the social, political and technological developments have substantially affected countries and social groups. Although these developments mostly 
upgrade the life standards of populations, they have adverse effects on low socioeconomic groups in different parts of the world. Erice is one of these places where technological and industrial advancements offer new business opportunities but are unable to rise the locals' life standards parallelly. Manves City used to be a natural place in the countryside and was populated by local people with great hopes for the future. After new factories are built by the holding, the industrialization period begins in Erice causing the emergence of working class which has not been heard there before. From now on, the class distinction is saliently marked there. There is a clear-cut distinction between the working class and the class who has the privilege in terms of family life, education level, political participation, and involvement with criminal justice system. The inversely proportional relation of these classes clearly manifests the social inequality caused by capitalism. As an ecosocialist John Bellamy Foster states "[A]ccumulation of capital was at the same time the accumulation of a laboring population, much of which remained unemployed and underemployed. Accumulation of wealth at the top of society was thus mirrored in the relative misery, toil, and dispossession at the bottom of society, upon which the entire system of capital rested" (Foster, 2020, p. 182). In the past, to improve workers' condition, the working class was protected by the rules that enabled them the right to organize, to be paid a minimum wage, to have limits on their working days, to have social security and more. Those rules were guaranteed by unions. However, the new millennium is like a monumental turning for reflection and assessment in business world with the effect of advanced technology. Accordingly, the number of labor unions and their strength over employers are on decline.

The workers in factories are forced to group within themselves and the groups compete each other harshly since their wages will be determined according to their performances in production. "The workers' passion to earn more money by upgrading their performance grades leads to a competition among groups, the rivalry escalated by bullying and teasing is getting more violent every month and turns into hostility" (Tekin, 2018, p. 16). The pressure over workers is exercised very systematically. The employers of Manves holding have developed an implementation initialized as WDEW. "For the workers who are forced to work till drop and smashed under the burden of the work and the debts, factories have turned into hell with the implementation called "Worker Doing Every Work" (Tekin, p. 14). The workers are exposed not only physical but also psychological oppression. "They were given unlivable lives; it is in vain how much they have devoted themselves to their work, the moment they are fired from work they will become worthless even for themselves" (Tekin, p. 19). Ersel used to be a worker before he was sentenced for five years for the crime that he had been vainly blamed. That time was the beginning of the industrialization process in Erice. On his return, he finds Erice transformed into a new formation. Alongside the environmental change of the town, the system which was relatively respectful to labour rights has already evolved into a new order. In this sense, the suicide of Ersel's father, who used to be an ex- unionist, embodies that the established order has already vanished and the new system has been settled among the workers. In this system, the workers happen to find themselves in the rat race. They are deprived of most of their rights at work as well as they have to abandon some social and moral values in their lives.

Such devolution is not immediately effective and perceptible, instead it has belated effects which are dispersed time and space. Manves holding, the embodiment of capitalism, systematically and incrementally manipulates the workers' lives by setting oppressive rules 
which also affect social and domestic codes in the society. This oppressive system overlaps with Rob Nixon's notion of "slow violence" that is mostly employed in environmental studies. However, given that environmental themes have intermingled with social, political sciences and humanities in the past few decades, slow violence manifests itself in the big transformation of Erice with respect to ecological and social tribulations. According to Nixon's claim, the people who are exposed to slow violence more are mostly impoverished ones. Impoverishment includes numerous local variations under the taxonomy of gender, race, ethnicity, class, region, religion or generation. In respect to Erice, the slow violence is exercised over the class distinction. Since the industrial process started in Erice, Manves holding has exploited the working class in accordance with its own benefits and ignored the workers' needs and left them impoverished. Nixon claims that such communities are often assailed by a restrictive and oppressive authority to sustain and strengthen its existence in the system. Moreover, the accretive effects of capitalism on the society are frequently accompanied by environmental deformation as seen in Erice. As Ecosocialism claims "ecological destruction is not accidental feature of capitalism, it is built into the system's DNA. The system's insatiable need to increase profits - what's been called the ecological tyranny of the bottom line - cannot be reformed away" (Angus, 2007, p. 1). In the same vein, the spatial and dispersed effects of capitalism are explicitly featured in Erice's environment. According to Nixon, the most common examples of slow violence are "petro-imperialism, the mega-dam industry, out-sourced toxicity, [...] forces that disproportionately jeopardize the live hoods, prospects, and memory banks of the global poor" (2011, p. 5).

For example, in order to produce more energy for the factories, Manves holding constructs a dam in Pirasa Ovasi. The landowners have to sell their fields, farms and gardens since "Manves Dam all swallowed this fertile valley" (Tekin, 2018, p. 59). The construction of the dam has already upset the natural balance. The author describes the change with these words, "[...] the spring of water flowing to the fountain once abounded with fish, people went there to vow, the fish were jumping around, there were nice smelly trees, and now they kept the water, Nergis has told, they did not let the water run down, the dam has been built" (Tekin, p. 59). Moreover, although there have been sets of environmental laws and standards that regulate mining operations in national basis, in Erice " $[. .$.$] there emerged$ families who can have a mining license as easy as having a taxi license, they have been talking about families who have already stored rolls of licenses in their so-called License Library" (Tekin, p. 87). In this circumstance, Manves holding has already become a monopoly controlling the natural resources for its own benefits.

Not only the natural resources are exploited in Erice but also the environment has been corrosively affected. The town which used to be an agricultural center with its fertile lands has turned into a dull place parceled by Manves holding in order to erect new factories. In the narrative, Tekin also uses the epistolary format to inform the readers about what has happened to Erice. Ersel's old friend Nergis writes letters to him when he was in prison. She writes "It necessarily means that the time has already come to ask where we head for if there left too little place for two ploughs in Pirasa Ovası which has been called as green sea by our ancestors" (Tekin, 2018, p. 44). The change is so distinctive that the panorama of the town has been evolved into the place that is completely unfamiliar to the locals. "The plain has been covered by factory buildings which are located as if they were green houses, the fields are arranged like the order of army huts, no one has considered to spare a tiny green place for the one who wants to enjoy the scenery. A helicopter has taken 
off and disappeared among the clouds, its whirring in the sky has echoed on the hillsides" (Tekin, p. 66). Nothing remains the same in Erice and the locals seem to adapt to this new formation without giving any reaction. At this point, Nixon states "As such, impoverished resource rebels can seldom afford to be single-issue activists, their green commitments are seamed through with other economic and cultural causes as they experience environmental threat not as a planetary abstraction but as a set of inhabited risks, some imminent, others obscurely long term" (2011, p. 4). Because of oppressive practices exercised over Erice's people by capitalist forces, it becomes more difficult for them to perceive the global environmental degradation and the ecological threats in planetary level. Accordingly, many environmental disasters go unnoticed in Erice.

\section{Societal Tribulations in Erice}

In the narrative, most of the people work for the capitalist institution, Manves holding which wants to garner the highest possible profit from Erice by paying the least attention to the environment. In Joel Kovel's words, the holding literally turns the environment "into a fresh source of profit" (2007, p. 176). In the same vein, another ecosocialist, Löwy asserts that "[R]ationality limited by the capitalist market, with its short-sighted calculation of profit and loss, stands in intrinsic contradiction to ecological rationality, which takes into account the length of natural cycles" (2005, p. 19). As such, Manves holding with its self-centered tunnel vision has already destroyed ecological balance. Ecosocialists believe that the recent environmental disasters arising from the destruction of ecological balance have rooted in societal tribulations. Erice becomes a place with lots of societal problems since the foundation of Manves holding. In the novel, the social problems are reflected through various narrators whose incompatibility with Erice 's big transformation is clear.

The workers' petitions and letters of complaint are among the different narration types that Tekin has employed in the narrative. They are usually about the poor working conditions. "We have burnt mouth and hands; we do not want to drink tea with paper cup. You cannot force us work only with four olives and a tomato in the night shift" (Tekin, 2018, p. 17). Due to the principle of highest production rate, the workers are restricted in terms of their basic needs. "They do not care our objection about the 15-minute toilet permission. The time is not enough to relax and we cannot meet our basic needs" (Tekin, p. 35). These messages reflect Tekin's socialist perspective and also provide an insight about the workers' condition. The workers not only demand an enhancement for their conditions but also their petitions mirror the changing face of the society. "We want a dance course. [...] We complain about the constant failure in the headphones of the robot supervisor. [...] The ones who have tattoos are not let to work overtime. [...] Surveillance cameras are also a problem. Their number have been risen from 60 to 70, we cannot breathe. [...] We ask for a psychologist" (Tekin, p. 75-6). The holding, then, turns out a kind of mirror on which the transformation arising from the capitalist practices and the modern changes of the $21^{\text {st }}$ century can be reflected.

Nergis's columns for a local newspaper telling the unfair practices of the employers and the ecological destruction in Erice revive the narration by adding a sincere tone of the first-person narrator. These texts include poetic expressions. Such a sentimental tone leaves a deep impression on the reader and also saves the novel from being a dull narration. Through Nergis's words, Tekin also succeeds to meet her feminist perspective with ecological issues:

SEFAD, 2021; (46): 139-152 
No one is a seed planted on this land but here's where we have blossomed. [...] If you rewind your lives you'll find your childhood but not the natural wonder of Erice which gives you these days. The dreams of all from the young to the old are entrusted to the women. Can you compare the one who lays the tablecloth under the cherry tree and the other laying it on the concrete floor? Who cares whether the world is revolving or not after the women's alter, wish fulfilling spring Three Gutters dry up (Tekin, 2018, p. 33).

Socialist ecofeminism claims a connection between the exploitation and degradation of the natural world and the oppression and subordination of women. At this point, Manves City can be marked as a novel which is also adequate to such criticism.

As a branch of ecofeminism, socialist ecofeminism argues that woman is also exploited in the production-economy system as so nature is. Socialist ecofeminists "perceive the systems of capitalism and patriarchy as interactive, mutually reinforcing, and inseparable for the purposes of feminist analysis" (Carlassare, 2000, p. 5). Because of the multifaceted and intertwining connection of patriarchy and capitalism in the issue of women's oppression, socialist ecofeminists perceive both systems as one. Their argument is based on women's secondary position and underpaid labour in patriarchal capitalism. Referred to the analogy between woman and nature in a way that nature has been given subordinate position as a result of anthropocentrism, it is not surprising that capitalism has been exercising more privileged practices for men. In this respect, an ecofeminist Ariel Salleh puts forward that "[c]ontinued capital accumulation and the expanding hegemony of transnational operations deepens nature's and women's subjection" (1995, p. 22). In the novel, the capitalist patriarchy reinforces women's subordination. In the letter written by a female worker to the human resources of the factory, the patriarchal hegemony in the work domain becomes apparent. The woman has been sexually harassed since her fiancé was fired due to the physical and verbal conflict he has had with a foreman. The foreman who has been insistently harassing the woman also threatens her to dismiss from her current position. "What if he drags me to the air conditioner room in the night shift, I cannot get rid of him. Since he is the foreman and also the imam in the factory, he never takes the blame on himself. When I ask not to write my name on the night shift list, he says you deal me first then I can figure your problem out" (Tekin, 2018, p. 33). Therefore, she is not only exposed to sexual harassment but also has to renounce the overtime pay that is given to the night shift workers. The capitalist patriarchal mindset similarly exploits nature attributing both women and nature the role of "other" while casting the role of "self" for itself. According to socialist ecofeminists, in this hierarchical dualism, the reason of environmental degradation and women's oppression lies.

The systematical and technological changes of $21^{\text {st }}$ century have deep repercussions on a communal and individual basis in post-industrial towns. From a sociological perspective, one of these impacts is alienation which can be defined as a feeling of helplessness, purposelessness and estrangement as a result of being unable to find accomplishment in one's work. The idea was encapsulated in Karl Marx early writings claiming that "the agrarian, handicraft economy" was being replaced by "industry machine manufacture" (Britannica, 2015, p. 504). Before the Industrial Revolution, work was more imaginative and modifiable, for example, craftsmen worked based on their own schedule and had a total control on what and how they made it. Similarly, agricultural work varied according to the seasons and the product was vitally important, which made the work meaningful. 
Conversely, factory workers do not have so much control on the production process, working hours or the finalized product because of the involvement of technology. They are supposed to perform repetitive tasks producing something that is not necessarily vital for them but creates fortune for their employers. Workers become alienated to employers and each other due to the class distinction and harsh competition, the new form of collaboration (Kellner, 2006). Therefore, as Marx claims, work becomes "dehumanized" and no longer includes enthusiasm of self- realization. (Fulcher \& Scott, 2003).

The alienation problem at work causes societal tribulations which primarily affects family life. The changes at work urged by capitalist practices gradually penetrate the family life. As the pillar of society, family no longer performs the role of maintaining the wellbeing of its members and plays its typical role as a support system. Moreover, it becomes the core of the problem. The concept of family is undermined and its structure has been shattered. The town abounds with broken families. The relatives in Erice are depicted through step relationship since almost all people have stepmother, father, aunt or uncle. For example, Ersel lives with his stepfather, Serco is Ersel's step uncle, Vedanur is Eda's step aunt and Çiğdem is Nergis's stepsister. Also, Çiğdem has a stepmother in law. As Tekin well states "Everybody has a step relation with one another in Erice $[\ldots]$ if you get in any quarter, you'll find heaps of relatives, all of them are step" (Tekin, 2018, p. 27). Tekin reflects the psychological problems stemming from such relations through Zeynur, who elopes with Serco. Serco is Zeynur's husband, Ersel's step uncle. At this point, Zeynur's diary which is found and started to be read by Ersel appears as another way of narration. Zeynur's writings reveal the psychological state of a person from a broken family. Her alcoholic father has gone bankrupt many times. Her mother is a control freak and has to look after three stepdaughters each of whose mothers are different. In such a case, Zeynur has a lot of flaws in her character which lead her making wrong decisions and creating big communication gaps with other people. In her diary, she writes "Now I know, I was having panic attacks at that time, the idea of hurting my daughter on the edge of going insane is a terrible feeling. As they say I wish it did not happen even to my enemy. [...] There are some people passing by you while walking on the street, but you may never know they have been already dead; they are not zombies or such. They are only creatures in the human disguise" (Tekin, p. 8991). To her horror, Eda, Zeynur's daughter from her first husband, gets lost and later is heard to have been found dead in the middle of nowhere.

In the novel, there are many examples of physical violence in the family. Ersel has been exposed to violence many times by his alcoholic father. He even develops an attitude towards cats since they remind him his father, who feeds them with liver. "[h]is father often brings bloody liver wrapped in a piece newspaper. Its smell sometimes hits his face like a ton of bricks. He never takes pity on Ersel as much as he does on the cats, he almost watches for an opportunity to beat Ersel, that's why he does not like cats pretty much" (Tekin, 2018, p. 63). However, the violence Ersel has been exposed many times is beyond the effect of the physical harm of a kick or a punch. It evokes shame and anger dispersed across time and space. "Slow violence" as a concept, lends itself to this situation. It is required not to rely on the superficial definition of violence "as a highly visible act that is newsworthy because it is event focused, time bound and body bound" (Nixon, 2011, p. 3). Instead, it is needed to rethink "how the temporal dispersion of slow violence affects the way we perceive and respond to a variety of afflictions-from domestic abuse to posttraumatic stress [...]" (Nixon, p. 3). Considering Ersel's case, arresting symbols and images adequate to the belated effects 
of slow violence continuously haunt him throughout the story. In the same vein, such domestic afflictions turn into transgenerational traumas in a way that bury their roots and make their reasons difficult to find out and address. At this point, Zeynur's daughter Eda, who has been inherited many traumatic experiences, no longer bears the afflictions in her life and faces with a very tragic death at the end of the novel.

In Erice where the human relations are complicated and degenerated, it is not surprising that the relationship between human and nonhuman has also been dislocated. The ecosocialist Jorge Riechmann, on this point, often uses metaphors in order to manifest the world in which natural relationships are disrupted. He puts forward "the farmer's relationship with the seed has been dislocated, the shepherd dog's with sheep's, [...] the cotton's to the spinner's, the equation's with the trajectory's, the miner's with mining's, [...] of the worker's to the marketplace's" $(2007$, p. 59). In the same vein, humans' natural bond with the nonhuman has been broken and the reason of this fracture is shown as the advanced technological practices in the novel. On being released from the prison, Ersel starts working in a farm. Azim, the bailiff, is assigned to explain Ersel which tasks he is responsible from. He says "[t]he work has been already automatized, it flows mechanically, I don't get what to teach you, the meadow is surrounded by electric fence, once the cows get in the meadow they cannot get out. There is no need for human to herd the cows anymore, here's an electrical shepherd" (Tekin, 2018, p. 96). The effect of advanced technology is also felt at workplace. Because of the fast mechanization process, there will be less need for human labour in Manses City. Through the conversation between Ogün, the vet of the farm and Ersel, it becomes apparent that the construction of a new unmanned factory is quite near and accordingly the rise in the number of the unemployed is assured. "They bought anywhere from here to our farm, they will erect a dark factory, unmanned with zero energy consumption, robots will make production" (Tekin, p. 60). In so doing, the job opportunity in Erice diminishes, which causes a harsh competition rather than collaboration on the contrary to Riechmann's statement which tells "to cooperate, not compete, made us human" (2009, p. 240). In this way, the people in Erice are left hopeless and become alienated each other. Based on the ecosocial idea that it is impossible to consider societal tribulations and ecological problems separately and also the former causes the latter, the destruction of the environment in Erice can be viewed as an extension of the system of dominance, competitiveness and individualism on which the dynamics of capitalism and production hinged.

In her column for the local newspaper, Nergis, once for all, writes about hope for the future. In her article entitled "Farewell Spring, Welcome Summer, she cherishes a new hope after losing her deep-rooted expectations for a prosperous future that she has ascribed to spring. She reproaches spring for not reacting against harassers, hunger, impoverishment, injustice, tricks in politics. As the symbol of rebirth or renewal, Nergis expects spring to stop all the afflictions around Erice and to start a new life where hopes for the future can flourish. However, after being frustrated by spring, Nergis relies on summer to fulfil her expectations. She writes:

Farewell to you spring, you just turn back and go with a sour expression on your face. Before going, turn and take look at Erice, have you ever offered something nice to the people of this town? I can silence my heart but it has been on my conscience ever since. I will all speak out your tasks that you owe to this society but you keep avoiding. [...] What 
good are you then if you did not give a hand for those who are struggling to decrease the inflation? If you could not wipe out the shame from the face of people who fed up with harassment and rape? [...] (Tekin, 2018, p. 105-15).

As a matter of fact, Nergis puts the blame on the season since she is unaware of the fact that the spring in her childhood is not the same and also is unable to fulfil people's expectations anymore. When she recalls her earlier memories, it becomes clear that the spring in her mind is completely different. "Spring has a particular place in the calendar of their friendship, when they remember each other, the bitter scent of purple red flowers is refined in the air. Their life story not only belongs to morning but also to spring" (Tekin, p. 25). On the contrary to the romantic and promising depiction of the spring from her past, the current spring deserves Nergis's condemnation and she welcomes to the summer as the new representative of her hopes. Tekin, in effect, tries to draw attention to the change in the environment by juxtaposing two different reflections of spring. The underlying reason of Nergis's frustration is the big transformation in Erice embodied in the abstraction of spring. As stated earlier, the modern changes in the $21^{\text {st }}$ century have caused the big transformation in terms of social and ecological paradigms. In this sense, it is capitalism that locates Erice on track of the socioecological chaos. As Kovel asserts "capitalism requires continual growth of the economic product, and since this growth is for the sake of capital and not real human need, capital's effect is the continual destabilization of an integral relationship to nature" $(2007$, p. 2). The fact that all ecosystems have physical limits, which contrasts with the idea of everlasting expansion intrinsic to capitalism causes ecological conflicts and the impoverishment of social stability as such in Erice.

\section{CONCLUSION}

Manves City portrays a place in which the exploitation of labour and the environment go hand in hand. The novel reveals that the two are reciprocally influential. This creates a scope for ecosocial criticism which stands against both industrial capitalism and globalization. The environmental degradation and societal tribulations are profoundly interrelated and could be read as different manifestations of the same structural force. The former mostly results from pervasive industrialization which disregards the fact that natural resources are not finite due to its infinite expansive pattern of production and consumption. The latter is derived from globalization which has disintegrative effect on societies in terms of culture, morality, identity and locality. Both serve for a single force; the expansion of the industrial capitalist system. It is the central dynamic in Latife Tekin's Manves City which depicts the post-industrial town Erice's big transformation. The environmental and societal tribulations make the novel prone to ecosocialist criticism that gives the priority to social and ecological wellbeing. Capitalism corrupts the representational systems of societies in the global South. Accordingly, Manves holding breaks down all social codes like moral values, class systems, kinship and religious beliefs, which leads to societal tribulations in Erice. These changes have belated effects overlapping the idea of slow violence that is mostly exercised in regions with low income. The accretive and attritional effects of slow violence are saliently marked on individual and communal basis in Erice. All the characters are frustrated with life in different ways in the narrative; the feeling of being lost and despair always lurks in the air for Ersel, Zeynur has gone mad and Nergis is surrounded by the longing for nostalgia that she cannot get rid of despite her strong hopes for a better future. As another main character, Erice, which is cast a stereotypical role of post-industrial town, 
has gone through a big environmental transformation. The ecological balance is dislocated in the town with irreparable consequences. The environmental disasters are mostly disregarded by the people in Erice whose green commitments fall behind their economic and social afflictions. Therefore, the society and the environment are being gradually corrupted under the guise of the advancements that are launched by industrial capitalism and globalization. Despite this corruption, in Manves City, Latife Tekin flourishes a hope for salvation. She associates the hope for enhancement in the society and the environment with Eda, who has gone missing from the beginning of the novel. Ersel believes that he can survive if he finds and saves Eda. In his survival, there also lies the hope for Erice's future. Unfortunately, these hopes fade away when her naked body with a tattoo of bird and flower on her left shoulder is found. Her dead body not only manifests the climax of societal tribulations in Erice but also the loss of hope for the environmental remediation. A crucial insight of Manves City, then, reveals the fact that the industrialization of the world, the dominance of industrial institutions on workers and the corruption of the environment are intimately linked in the reflection and praxis of the global capitalism.

\section{SUMMARY}

Ecosocialism aims at combining environmental thinking with socialist perspective in order to have a classless and more equal society which is in harmony with nature. In this study, the theory is accompanied by another concept, "slow violence" coined by Rob Nixon. This way of violence has effects which are not immediate but dispersed time and space. Ecosocialism which criticizes the gradual exploitation of society and nature can overlap with the concept of "slow violence." Defined herself as a socialist author, Latife Tekin portrays the environmental and social effects of slow violence in Manves City where a post-industrial small town and its inhabitants' tragic lives are portrayed. The novel reveals that the exploitation of labour and environment has some analogies as both could be read different reflections of the same global economic system named capitalism. These reflections can be mainly observed on society and environment as the readers can do in Manves City which depicts Erice's transformation into a post-industrial city. Firstly, societal tribulations especially in underdeveloped countries, are derived from capitalism. Similarly, Manves holding, a local corporate, disrupts the social codes like moral values, religious beliefs, familial bonds but creates clear cut distinctions among social classes. This transformation has belated effects on the people's lives in Erice which is described in the novel as a region with low income. In individual and communal sense, the accretive and attritional influences of slow violence are saliently noticed. All the main characters in the story go through hard times psychologically; Ersel feels desperate and lost, Zeynur loses her sanity, and Nergis is trapped in her nostalgic feelings in spite of her strong hope for a better future. Erice, which is cast another character in the story, also goes through an environmental transformation as a post- industrial town. The environmental order is upset with irreversible consequences in Erice. About this environmental degradation, the people in Erice whose green commitment falls behind their financial and social anxieties.

Therefore, the society and the environment are simultaneously corrupted under the guise of the improvements that are introduced by capitalism. Despite the degradation in society and environment, in Manves City, nevertheless, Latife Tekin evokes a hope for salvation. This hope is embodied by Eda, the stepdaughter of Ersel. She is mentioned as a lost girl throughout the story. Ersel believes that he can also survive if he finds and saves 
Eda. Besides, he assumes that the future of Erice depends on her survival. However, this hopeful expectation dramatically disappears when Eda's naked body with a tattoo of bird and flower on her left shoulder is found. The body not only reveals the climax of societal degradation but also the end of the hope for environmental remediation. To this end, a close gaze at Manves City, manifests the fact that environmental corruption and social inequality and tribulations are all interrelated within the context of global capitalism.

Article Information

\begin{tabular}{ll}
\hline EthicsCommitteeApproval: & Exempt from the Ethics Committee Approval. \\
InformedConsent: & No participant. \\
Financial Support: & No financial support from any institution or project. \\
Conflict of Interest: & No conflict of interest. \\
Copyrights: & No material subject to copyright is included.
\end{tabular}




\section{BIBLIOGRAPHY}

Angus, I. (2007) Three meanings of ecosocialism. Online Magazine, http://www.internationalviewpoint.org/spip.php?article1366. Retrieved on 19. 12. 2014.

Carlassare, E. (2020). Socialist and cultural ecofeminism, allies in resistance. Ethics and the Environment. 5 (1), 89-106.

Industrial Revolution. (2021). In Encyclopedia Britannica. Retrieved from https://www.britannica.com/event/Industrial-Revolution.

Foster, J. B. (2020). The return of nature, socialism and ecology. New York: Monthly Review Press.

Fulcher, J., \& Scott, J. (2003). Sociology. Oxford: Oxford University Press.

Giddens, A. (1990). The consequences of modernity, Standford: Standford University Press.

Kellner D. (2006). New technologies and alienation, some critical reflections. Langman, L., \& Kalekin-Fishman, D (Ed.), The evolution of alienation, Trauma, promise, and the millennium. (pp. 47-67). Lanham: Md, Rowman \& Littlefield Publishers.

Kovel, J. \& Lövy, M. (2001). An ecosocialist manifesto. http,//www.iefd.org/manifestos/ecosocialist_manifesto.php. Retrieved on 16. 03. 2012.

Kovel, J. (2007). The enemy of nature, the end of capitalism or the end of the world? London: Zed Books.

Löwy, M. (2005). What is Ecosocialism. Capitalism nature socialism. 16 (2), 15-24.

Nixon, R. (2011). Slow violence and the environmentalism of the poor. USA: Harvard University Press.

Riechmann, J. (2007). Conversaciones entre alquimistas. Barcelona : Tusquets Print.

(2009). La habitación de Pascal. Ensayos para fundamentar éticas de suficiencia y políticas de autocontención. Madrid, Los Libros de la Catarata Print.

Salleh, A. (1995). Nature, woman, labor, capital, living the deepest contradiction. Capitalism nature socialism 6 (1), 21-39.

Tekin, L. (2018). Manves city. Istanbul: Can Press. 